\title{
Volcano-ice interactions at Prestahnúkur, Iceland: rhyolite eruption during the last interglacial-glacial transition
}

\author{
D.W. McGARVIE, ${ }^{1}$ J.A. STEVENSON, ${ }^{2}$ R. BURGESS, ${ }^{3}$ H. TUFFEN, ${ }^{2}$ A.G. TINDLE ${ }^{1}$ \\ ${ }^{1}$ Department of Earth Sciences, The Open University, Milton Keynes MK7 6AA, UK \\ E-mail: d.mcgarvie@open.ac.uk \\ ${ }^{2}$ Environmental Sciences, Lancaster University, Lancaster LA1 4YQ, UK \\ ${ }^{3}$ School of Earth, Atmospheric and Environmental Sciences, University of Manchester, Oxford Road, \\ Manchester M13 9PL, UK
}

\begin{abstract}
Prestahnúkur is a $570 \mathrm{~m}$ high rhyolite glaciovolcanic edifice in Iceland's Western Rift Zone with a volume of $0.6 \mathrm{~km}^{3}$. Uniform whole rock, mineral and glass compositions suggest that Prestahnúkur was constructed during the eruption of one magma batch. Ar-Ar dating gives an age of $89 \pm 24 \mathrm{ka}$, which implies eruption during the transition (Oxygen Isotope substages $5 \mathrm{~d}$ to $5 \mathrm{a}$ ) between the Eemian interglacial and the Weichselian glacial period. Prestahnúkur is unique among published accounts of rhyolite tuyas because a base of magmatically-fragmented tephra appears to be absent. Instead, basal exposures consist of glassy lava lobes and coarse hyaloclastite, above which are single and multiple lava sheets with matrix-supported basal breccias and hyaloclastite upper carapaces. Steepening ramp structures at sheet termini are interpreted as ice-contact features. Interactions between erupting magma and water/ice have affected all lithologies. A preliminary model for the construction of Prestahnúkur involves an effusive subglacial eruption between 2-19 years duration which never became emergent, into an ice sheet over $700 \mathrm{~m}$ thick. If $700 \mathrm{~m}$ of ice had built up during this interglacial-glacial transition, this would corroborate models arguing for the swift accumulation of land-based ice in rapid response to global cooling.
\end{abstract}

\section{INTRODUCTION}

An important focus of climate research is the transition from interglacial to glacial conditions. The most recent such transition between the Eemian interglacial and the Weichselian glacial (Imbrie and others, 1989) was a period involving climatic instability linked with rapid temperature fluctuations (Guiot, 1990; Follieri and others, 1989; McManus and others, 1994).

The main aims of this paper are to present a model for an Icelandic rhyolite eruption that occurred during this transition, and to show how studies of ice-volcano interactions combined with Ar-Ar dating can provide improved estimates of past ice thicknesses. (Detailed accounts of the physical volcanology and petrology of Prestahnúkur will be published elsewhere.)

\section{GEOLOGICAL SETTING}

Prestahnúkur is an isolated rhyolite edifice (Fig. 1), elliptical (2.5 km NNE-SSW axis and $2 \mathrm{~km} \mathrm{WNW-ESE}$ axis), with a volume of $\sim 0.6 \mathrm{~km}^{3}$ dense rock equivalent (DRE). The summit of $1226 \mathrm{~m}$ lies $\sim 570 \mathrm{~m}$ above the lowest exposures (roughly defined by the $650 \mathrm{~m}$ contour). Its northwest flanks are overlain by the $1069 \mathrm{~m}$ high Hádegisfell syðra (a basalt glaciovolcanic edifice), and its east-northeast flanks may be overlain by the $1390 \mathrm{~m}$ high Geitlandsjökull basalt tuya; however, contacts are obscured by scree. Glaciated beds of basaltic hyaloclastite (which probably originated during the formation of Geitlandsjökull) occur across much of the edifice, which are usually $<0.5 \mathrm{~m}$ but occasionally up to $6 \mathrm{~m}$ thick and contain rhyolite clasts from Prestahnúkur, particularly in the coarser beds.

\section{VOLCANOLOGICAL OBSERVATIONS}

Prestahnúkur can be subdivided into three lava tiers: upper, lower and southern (Fig. 2). The lower tier is only exposed on the west flank, where it crops out continuously for nearly $2 \mathrm{~km}$. The upper tier forms a summit plateau and feeds slopedraping lava sheets on the southeast and east flanks. The southern tier lies beneath the upper tier and feeds slopedraping lava sheets on the south and southwest flanks (Fig. 2). While it is possible that all three tiers originally formed one high-level tier that was dismembered by normal faulting, the amount of throw required (over $300 \mathrm{~m}$ ) seems unlikely given the much smaller throws on nearby faults (Piper, 1973; Saemundsson, 1992). The various lava and fragmental lithofacies are now described and interpreted.

\section{Fragmental lithologies}

A range of fragmental lithologies are present. These are broadly divided into four groups: (1) lobe-bearing breccias; (2) coarse polymictic breccias; (3) well-bedded breccias, sandstones and gravels; and (4) pumice-ash breccias.

\section{Lobe-bearing breccias}

These dominate the lower parts of the edifice and may constitute $>30 \%$ of its total volume. They form a clastsupported breccia of coarse and moderately vesicular or micro-vesicular blocks (pale grey and flow-banded), normally less than $10 \mathrm{~cm}$, but ranging from $2 \mathrm{~cm}$ up to $1 \mathrm{~m}$ in size (Figs 3 and 4), with slightly elongate vesicles oriented parallel to flow bands. The blocks are often prismatically jointed and variably fractured (jigsaw fit), while abundant grey, silty ash infills fractures. Within the breccias occur shattered but coherent glassy lava lobes (up to $10 \mathrm{~m}$ in size) 


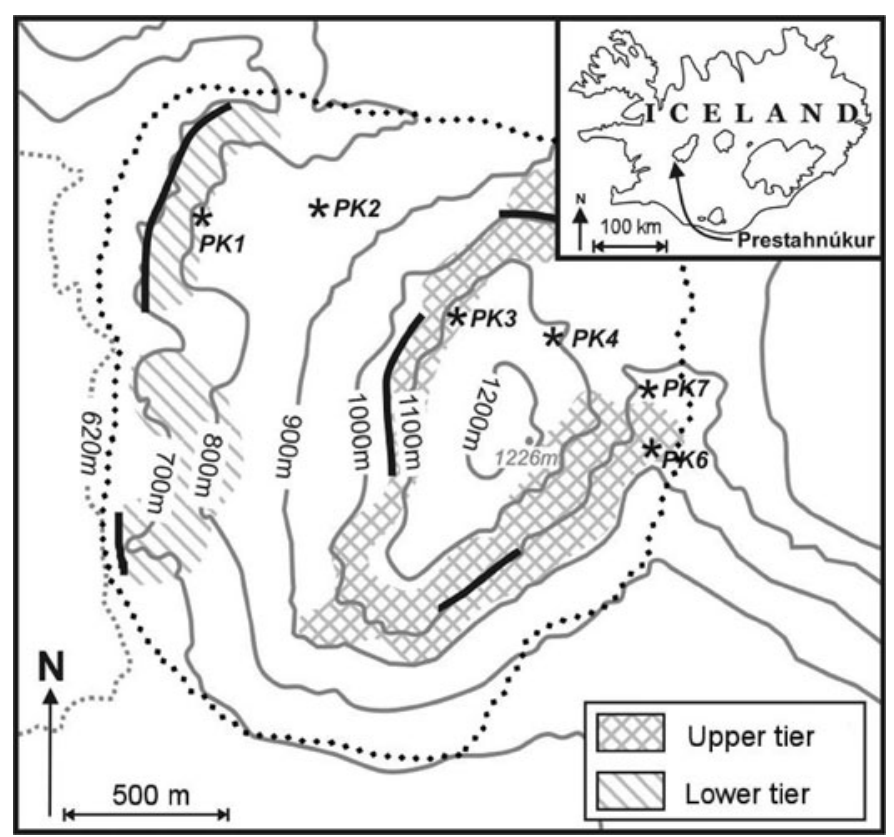

Fig. 1. Outline map of Prestahnúkur, depicting localities of analysed samples and the extent of the edifice (dotted line). For simplicity, the upper and southern tiers have been combined. Black lines indicate localized steepening at sheet termini.

which show irregular columnar joint development (usually $<10 \mathrm{~cm}$ ) with hackly and pseudopillow fractures (Lescinsky and Fink, 2000) and whose margins grade into the surrounding breccia. This lithology shows little evidence of oxidation, and has been extensively perlitised.

Quenching (by water) can explain the observed combination of abundant obsidian and glassy textures, the matrix of ash, the lack of oxidation and the generally smaller block size when compared to subaerial rhyolites (Anderson and others, 1998). While smaller blocks can be generated during high effusion rates (Anderson and others, 1998), the higher proportions of obsidian glass and ashy matrix (relative to subaerial lavas), the extensive fracturing of the lava lobes (Lescinsky and Fink, 2000) and the extensive perlitisation of the lobes and breccias all suggest that external water was present during the eruption. The breccias are therefore

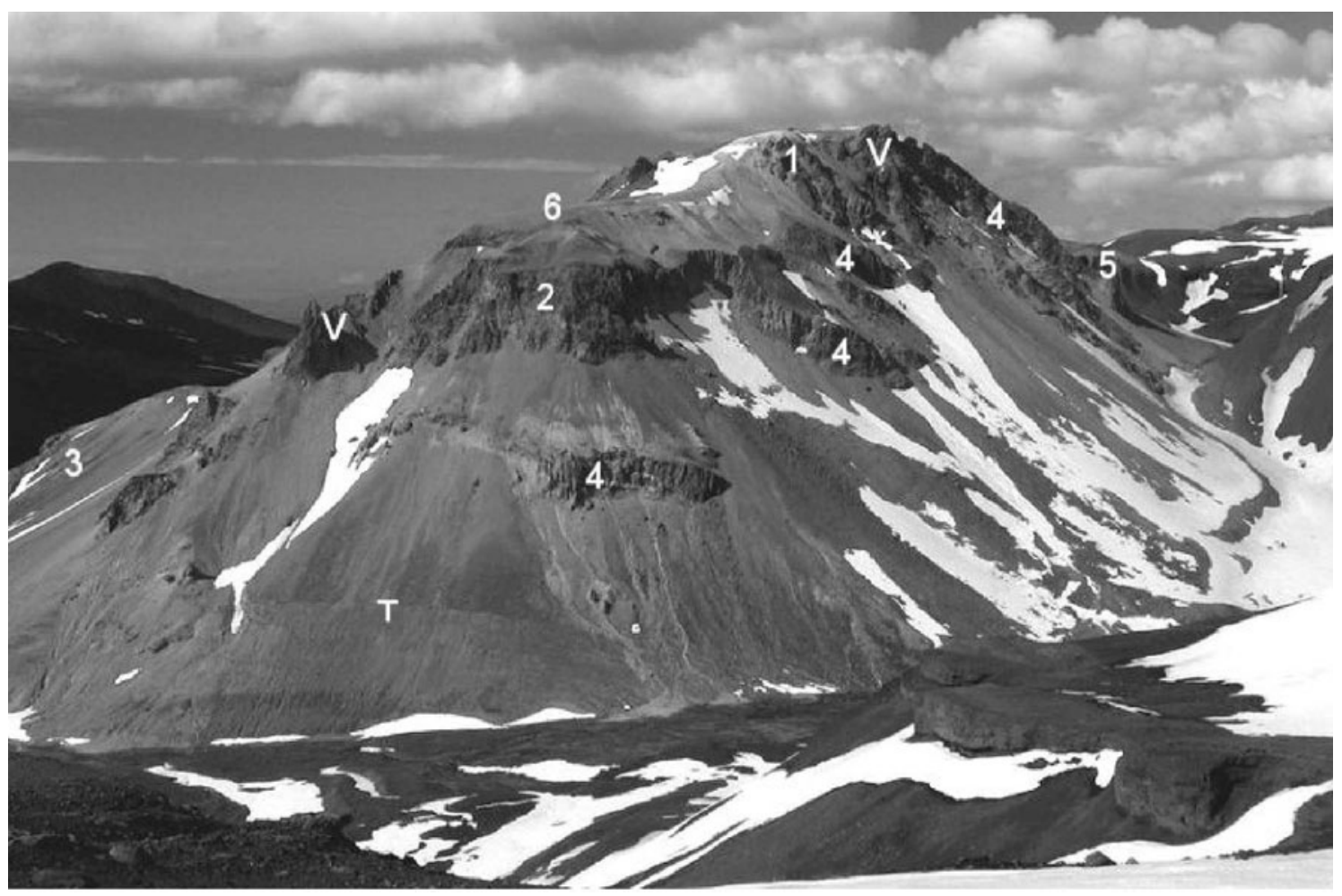

Fig. 2. Prestahnúkur from the South: 1 - upper tier; 2 - southern tier; 3 - lower tier; 4 - slope-draping sheets; 5 - hyaloclastite carapace (see Figure 7); 6 - single sub-horizontal sheet; and V - vents. A glacial trim-line is visible on the lower left of the edifice (T). 


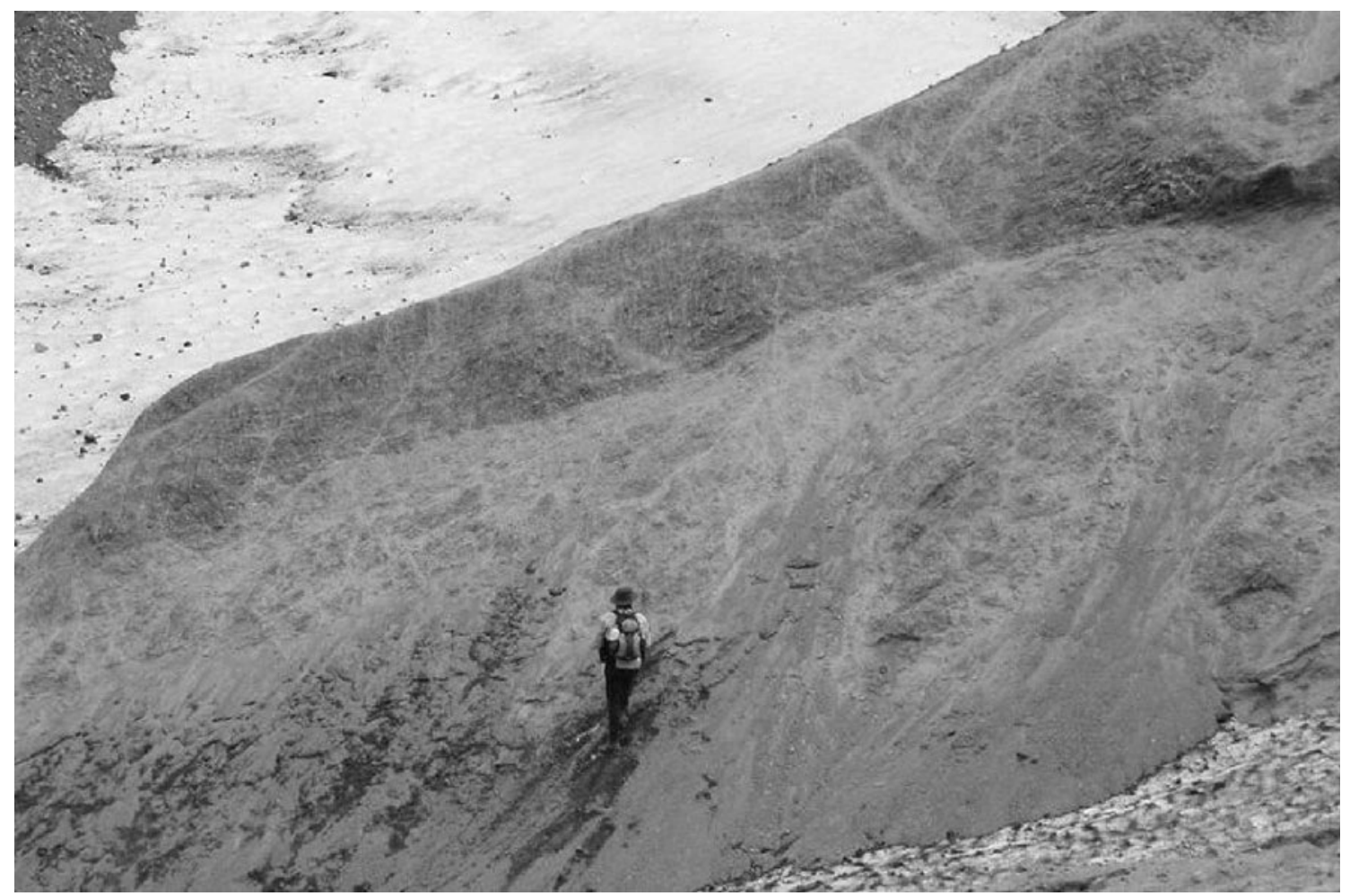

Fig. 3. Typical highly-perlitised lobe-bearing breccias at base of edifice. Person is $1.85 \mathrm{~m}$ tall.

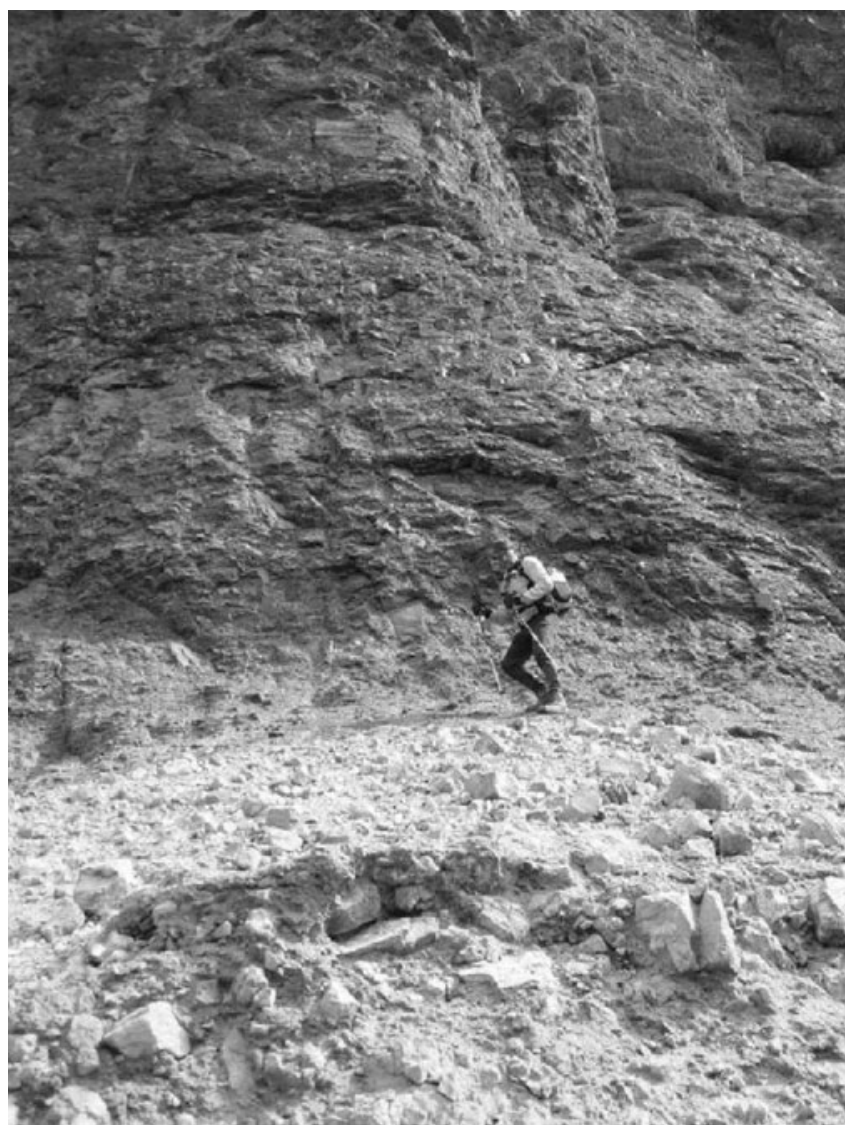

Fig. 4. Contact between lower tier lava sheet and underlying substrate: hyaloclastite of the lobe-bearing breccias grades upwards into matrix-supported breccias and then into undisrupted lava. Person is $1.85 \mathrm{~m}$ tall. interpreted as the quenched outer carapaces of the lava lobes: they are hyaloclastite (Goto and Tsuchiya, 2004). Lobe-hyaloclastite complexes are commonly formed by subaqueous eruptions of silicic magmas (e.g. Goto and Tsuchiya, 2004; Stewart and McPhie, 2006). This lithology is therefore broadly analogous to the pillow lava sequence found at the base of basaltic tuyas, where extensive interaction with meltwater is well established (e.g. Smellie, 2000). However, other lithologies characteristic of true subaqueous rhyolite eruptions (e.g. re-deposited hyaloclastite) are absent (Yamagishi and Dimroth, 1987; DeRita and others, 2001; Stewart and McPhie, 2006).

\section{Coarse polymictic breccias}

This lithology occurs at all stratigraphic levels in a variety of forms. Only two examples are given here: (a) self-supported angular clasts $(<20 \mathrm{~cm})$ of flow-banded rhyolite $(\sim 50 \%)$, microvesicular rhyolite (40\%) and obsidian (10\%) in an ash matrix; and (b) clast-supported polymictic breccia with angular clasts up to $10 \mathrm{~cm}$ dominated by microvesicular rhyolite clasts (with only minor clasts of obsidian or flowbanded rhyolite).

Example (a) is interpreted as the deposits of pyroclastic density currents (block and ash flow) generated by small explosions and collapses of lava bodies during extrusion; such explosions were common during the emergent phases of the 1953-57 Tuluman eruption (Reynolds and others, 1980). Example (b) is interpreted as the quenched carapace of a lava body and/or the product of glacial reworking of such material.

\section{Well-bedded breccias, sandstones and gravels}

Isolated exposures of well-bedded volcaniclastics occur on the edifice (Fig. 5). The beds are usually shallow-dipping 


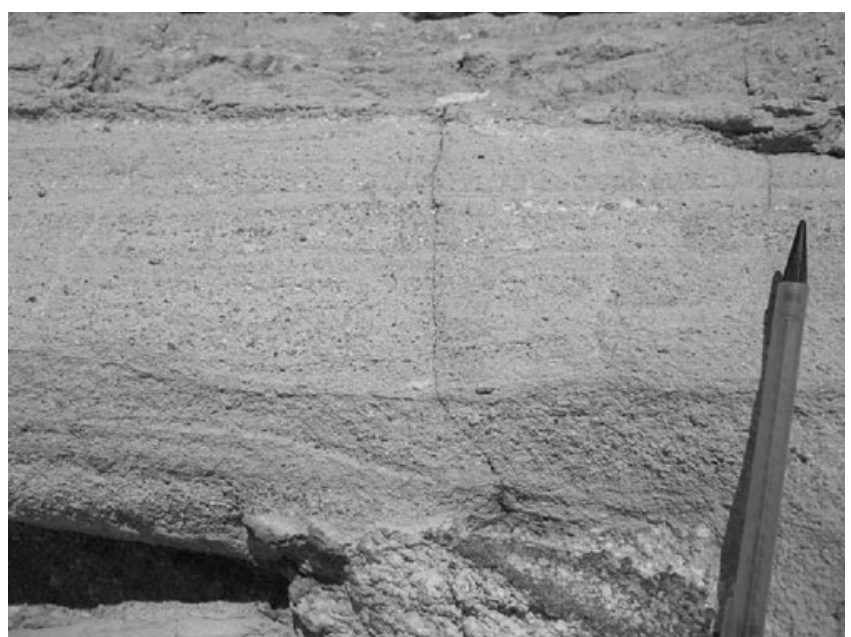

Fig. 5. Bedded volcaniclastics. The sorting and well-defined bedding are interpreted as deposition within water (following transport in debris flows). This suggests that regions of ponded water existed at the edifice at different levels and times during its construction. Length of pencil within image is $15 \mathrm{~cm}$.

with a variety of orientations (including dipping back into the slope). Beds range from $1 \mathrm{~m}$ to $<5 \mathrm{~cm}$ in thickness, with better sorting in the thinner and finer-grained beds. Although some exposures contain monolithologic beds (e.g. of grey microvesicular rhyolite, grading from coarse breccia into gravel and then sandstone), more commonly a variety of clast types (including obsidian and flow-banded rhyolite) occur. In the southwest, a $1.5 \mathrm{~m}$ thick sequence consists of $75 \mathrm{~cm}$ of well-sorted, diffusely cross-stratified brownish sand with obsidian granules, overlain by $75 \mathrm{~cm}$ of extremely fine ash. The basal part of the ash contains beds up to $2 \mathrm{~cm}$ thick bearing crystals and obsidian fragments.

This lithology, exhibiting sorting and well-defined bedding, is interpreted as the product of debris flows deposited in water. This suggests that regions of standing water existed at the edifice at different levels and times during its construction. Poor exposure does not enable the original sizes of the water bodies to be determined, but their localized nature suggests that they were small and isolated. Much of this material has been reworked from a variety of sources. The southwest locality, whose fine grain size in a proximal location indicates phreatomagmatic explosions (Cas and others, 1990), suggests that at least some of this material is primary in origin.

\section{Pumice-ash breccias}

This uncommon lithology forms beds up to $5 \mathrm{~m}$ thick containing angular clasts of both white (highly vesicular) and grey (moderately vesicular) pumice supported by a matrix of granules of pumice, obsidian and of fine ash. Such deposits form the bulk of the basal parts of other rhyolite tuyas (Tuffen and others, 2002; Stevenson, 2005) and were interpreted to have formed by magmatic (vapour-driven) fragmentation. They appear to be rare at Prestahnúkur.

\section{Fragmental lithologies - summary}

These fragmental lithologies represent the products of a range of eruptive styles and environments, and demonstrate that water, which was involved in both fragmentation and deposition, played a significant role throughout the eruption.

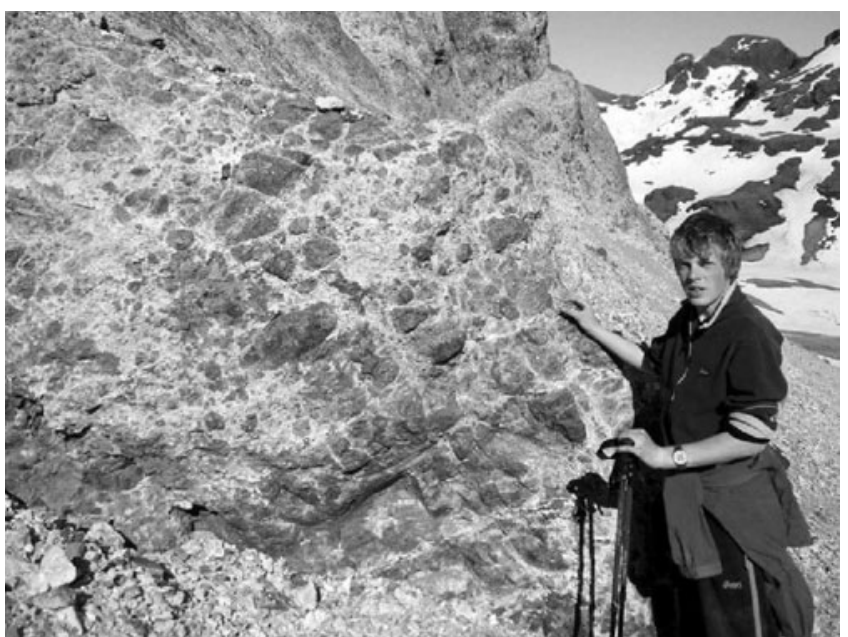

Fig. 6. Matrix-supported breccia at base of slope-draping sheet (southern tier). Both jigsaw-fit and clast-rotated domains are present. Person is $1.90 \mathrm{~m}$ tall.

\section{Lava lithofacies}

The three lava tiers comprise single and multiple lava sheets of variable thickness $(\sim 5-60 \mathrm{~m})$ with orientations from subhorizontal to slope-parallel (up to $40^{\circ}$ ). The lower tier appears to consist of one sheet some $30-60 \mathrm{~m}$ thick, $\sim 2 \mathrm{~km}$ wide, which probably flowed $<1 \mathrm{~km}$ from the (unexposed) vent. Both the upper and southern tiers (Fig. 2) comprise single and stacked lava sheets which have fed slope-draping sheets (up to $400 \mathrm{~m}$ long and $100-250 \mathrm{~m}$ wide). The constituent lava is strongly flow-banded with abundant lithophysae and spherulites constituting up to $80 \%$ of the rock; the largest lithophysae are $19 \mathrm{~cm}$ in diameter. General features of the lava sheets are described and interpreted.

\section{Sheet bases}

Lava sheet bases are underlain by a zone of interaction with the material beneath (Fig. 4). This zone comprises matrixsupported breccias up to $12 \mathrm{~m}$ thick (although $2-5 \mathrm{~m}$ is more typical) consisting of angular, flow-banded and glassy rhyolite clasts of variable size (Fig. 6) set in a matrix of ( $\mathrm{mm}$ to sub-mm) comminuted lava fragments and ash. Close to the lava, larger clasts $(10-30 \mathrm{~cm})$ define mainly jigsaw-fit domains. These grade outwards into smaller clasts defining both jigsaw-fit and clast-rotated domains.

These breccias are interpreted as the products of quench fragmentation of the lava sheet bases that flowed over soggy substrate, in a process akin to peperite formation (White and others, 2000), although sediment, sensu stricto, is not involved. Explosive mixing has been most energetic nearer the substrate contact, leading to comminution and back injection of the small lava clasts (derived from the sheet) and ash (derived from fragmentation of microvesicular substrate blocks). Larger jigsaw-fit clasts reflect only minor disruption of the sheet well above the zone of explosive mixing.

\section{Sheet tops}

Although sheet tops are poorly exposed (either removed by erosion or obscured by scree/till), massive interior lava (often glassy) can be seen grading upwards into carapaces comprising unconsolidated pale-to-reddish microvesicular pumice breccias (clast sizes typically $3-20 \mathrm{~cm}$ ), within which selvedges of flow-banded and contact-parallel obsidian 


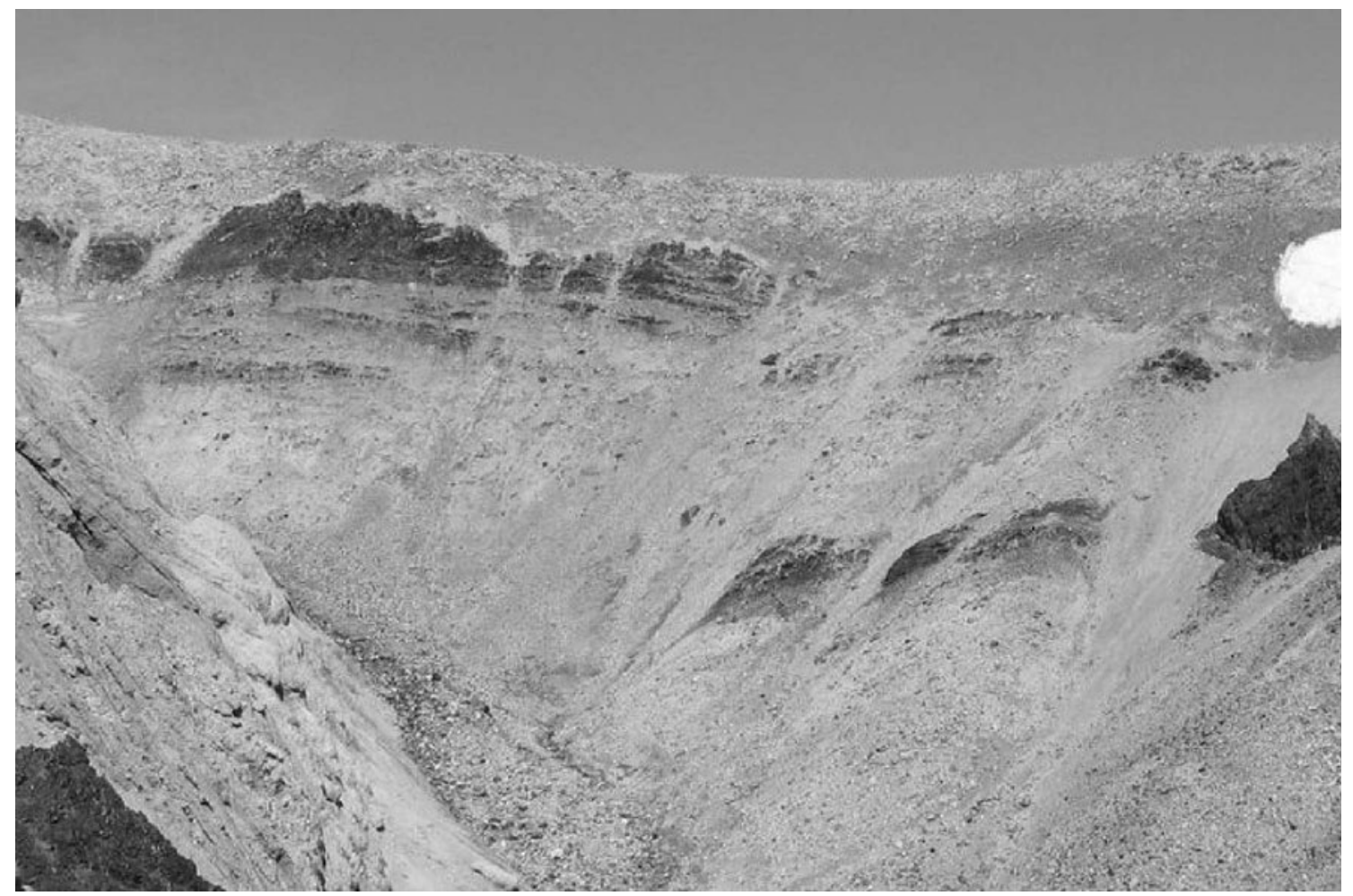

Fig. 7. Upper carapace of sheet showing hyaloclastite formation developing along flow bands, with remnant obsidian selvedges. Thickness of main obsidian band in upper left is approximately $3 \mathrm{~m}$. Note slope-draping sheet from upper tier on left, with pronounced flow layering.

occur (Fig. 7). Some sheets have carapaces up to $30 \mathrm{~m}$ thick, but $<10 \mathrm{~m}$ is more typical. Flow banding in most of the sheet is generally contact-parallel, but steep ramps develop in the (glassy) upper $\sim 5-10 \mathrm{~m}$ within which incipient brecciation can be seen. Where carapaces have been completely removed, lobes (glassy with small columns) are exposed (Fig. 8).

These carapaces comprise smaller blocks than the upper surfaces of subaerial rhyolites (typically $20-30 \mathrm{~cm}$, Anderson and others, 1998) and they are also much thicker (Fink and

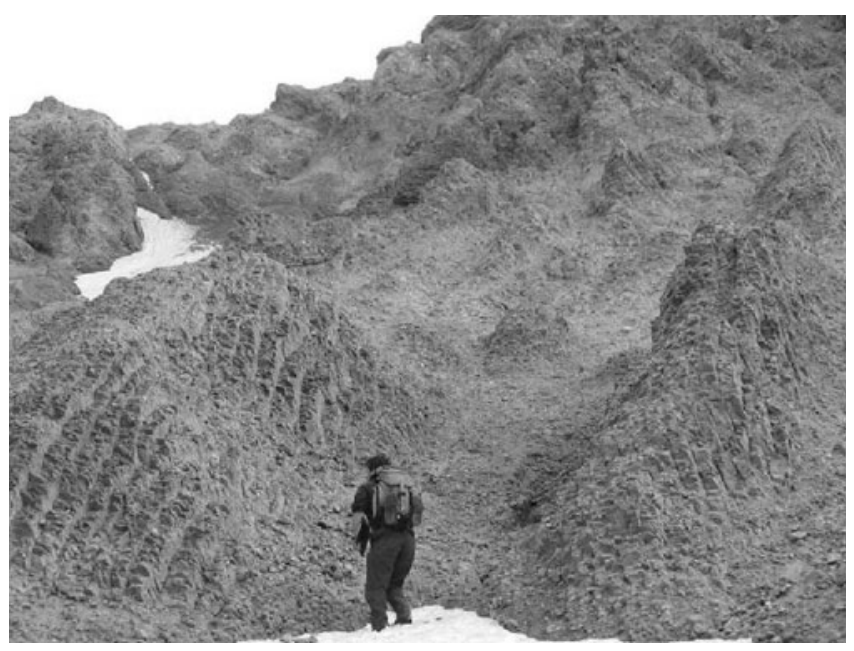

Fig. 8. Part of a steeply-dipping $\left(\sim 35^{\circ}\right)$ segment of the lower tier, where the upper carapace has been removed to reveal columnar jointed lobes. These are interpreted as the upper parts of sheets where they made contact with the base of the overlying ice. Person is $1.75 \mathrm{~m}$ tall. others, 1992; Fink and Anderson, 2000; Stevenson and others, 1994). They are more akin to the hyaloclastite carapaces of silicic sills described by Hunns and McPhie (1999) and Orth and McPhie (2003). This implies that the sheets were wetted from above and that brecciation (i.e. hyaloclastite formation) was encouraged by water accessing upper parts of the flow via downward-propagating tension cracks (Stevenson and others, 1994).

\section{Sheet termini}

A number of sheets (both sub horizontal and slope-parallel) terminate in steep glassy walls (Fig. 9), with flow banding steepening dramatically towards the vertical over short distances $(<50 \mathrm{~m})$ and in extreme cases becoming overturned. The tips of downward-propagating tension cracks associated with brecciation are often prominent.

We interpret the localized steepening of flow banding at sheet termini as ice-contact features, where (ice) resistive forces became higher than the forces promoting flow of lava. Much of the entire $\sim 2 \mathrm{~km}$ long termini of the lava sheet comprising the lower tier shows this localized steepening, which also occurs at some upper tier flows (e.g. at $\sim 1100 \mathrm{~m}$ altitude on the north flank). Overturning of flow ramps may suggest pinning of the lava sheet's upper surface to an ice roof while ductile flow continued below.

\section{Sheets - summary}

We consider the sheets to represent sills that intruded iceedifice interfaces (Wilson and Head, 2002), with intrusion of the slope-draping sheets being aided by gravity. Meltwater played a key role in sheet formation: basal breccias indicate both quenching and explosive mixing, while brecciation at flow ramps and upper carapaces indicate sustained wetting (and penetration of water) from overlying ice. Steeply 


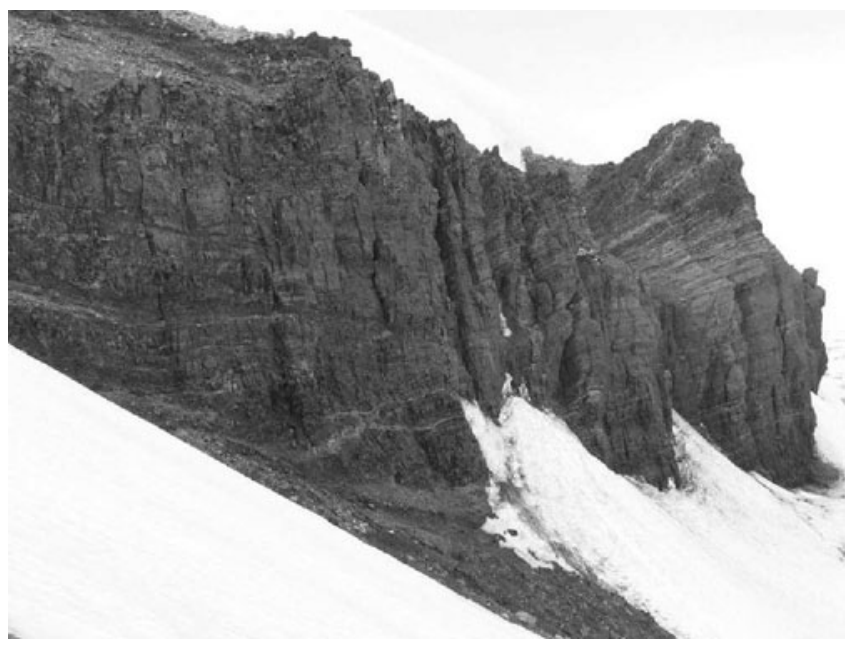

Fig. 9. Termini of sub-horizontal sheet at $\sim 1100 \mathrm{~m}$ on the north flank, interpreted as an ice-contact feature. Flow banding is prominent (often picked out by localized lithophysae development). Between the uppermost flow bands are incipient hyaloclastite-breccia zones, which progress in fully developed form to those seen in Figure 7. Height of RH cliff edge is $\sim 45 \mathrm{~m}$.

ramped flow termini may indicate that ephemeral gaps existed between the growing edifice and the enclosing ice (perhaps aided/created by meltwater escape).

\section{Vents}

Two vents have been identified. The first is near the summit (upper tier) where a steeply dipping carapace of finely vesicular pumice breccia partly encloses microcrystalline rhyolite (Fig. 10). This vent fed a $\sim 400 \mathrm{~m}$ long slope-draping sheet that travelled to the base of the edifice (Fig. 7). The second is in the southwest of the southern flank tier where again, a finely-vesicular pumice breccia carapace partly surrounds microcrystalline and lithophysae-rich rhyolite.

\section{GEOCHEMISTRY AND MINERALOGY}

To place discussions of ice-volcano interactions in context, it should be established whether a glaciovolcanic edifice has been constructed during just one eruptive event or during several events separated by substantial time gaps (Werner and others, 1996). We use geochemistry and mineralogy to establish this for Prestahnúkur.

Detailed studies of Icelandic rhyolites have shown that each magma batch possesses a unique geochemical signature (McGarvie, 1985; MacDonald and others, 1990), with rare exceptions being eruptions from zoned magma chambers (McGarvie and others, 1990). A robust sampling strategy should therefore analyse samples from three or more eruptive units spanning the duration of the eruption. If samples show near-identical trace element concentrations/ ratios then the edifice is likely to have been constructed by the eruption of a single magma batch. If differences exist then either the edifice has been constructed by multiple magma batches, or it is monogenetic but produced during a zoned eruption.

At Prestahnúkur, six rhyolites were analysed to determine the variability of erupted compositions (Table 1). Major and trace elements show a consistent composition for all six rhyolites with very little variability, even for the alkalis

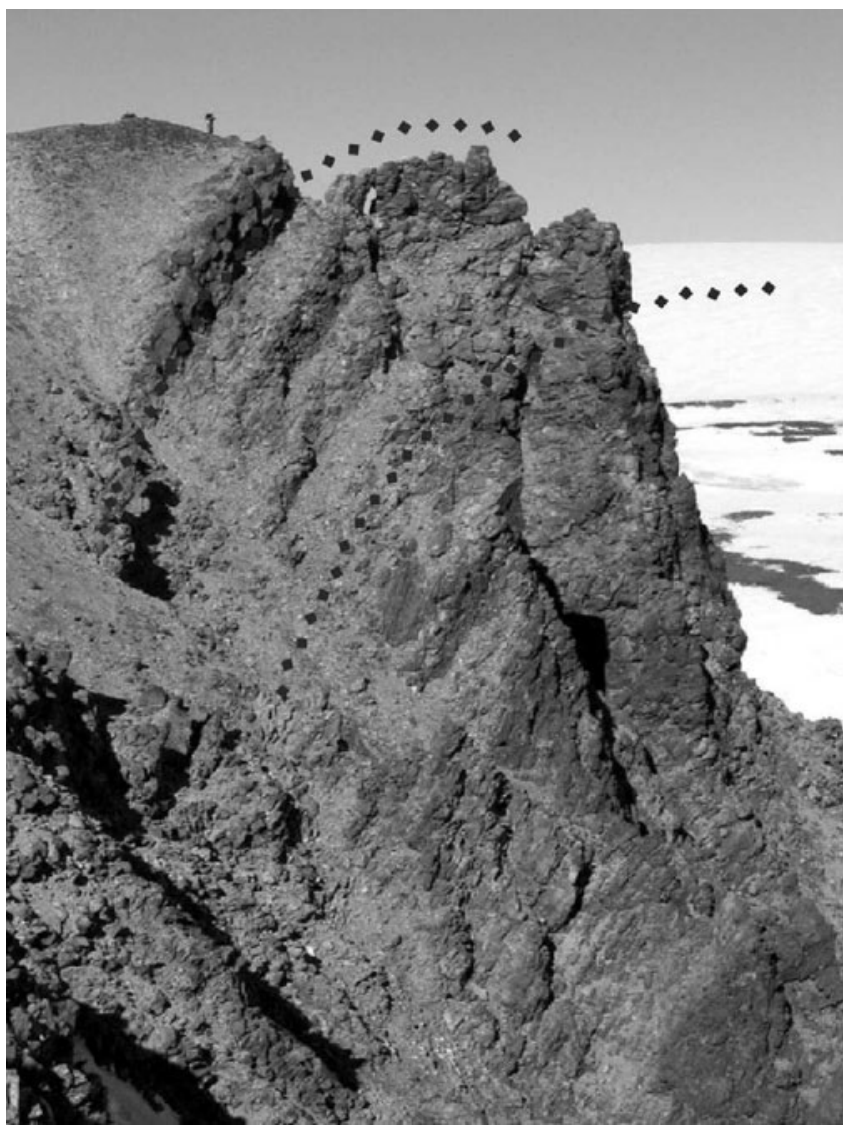

Fig. 10. The partly-eroded summit vent. Microcrystalline rhyolite forming the cliff is flanked on the left by a microvesicular carapace. Steep flow-banding (interpreted as upward flow) in the vent interior shallows to the right (highlighted by dashed curves). Figure (upper skyline) is $1.90 \mathrm{~m}$ tall; the summit cairn at $1226 \mathrm{~m}$ is immediately to their left.

$\left(\mathrm{Na}_{2} \mathrm{O}\right.$ and $\left.\mathrm{K}_{2} \mathrm{O}\right)$ which often show greatest variability (Baker and Henage, 1977). The rhyolites are sparsely porphyritic $(<8 \%$ crystals, with $\sim 1-4 \%$ being typical). Lath-shaped and tabular oligoclase feldspars up to $2 \mathrm{~mm}$ in size dominate, with most being around $1 \mathrm{~mm}$ although some larger grains reach $4 \mathrm{~mm}$. Other phenocrysts occur in accessory proportions: clinopyroxene (ferroaugite), fayalitic olivine, ilmenite and allanite. All phenocrysts show uniform compositions, while relationships between phenocrysts and glassy groundmass (i.e. euhedral phenocrysts showing no disequilibrium textures at their margins) suggest mineralmelt equilibria.

Essentially, consistent whole-rock, glass and mineral chemistry - corroborated by textures indicating no disequilibrium between mineral and glass phases - indicate that Prestahnúkur was constructed during the eruption of one magma batch over a sufficiently short time span that did not allow for chemical and petrological differentiation of the magma feeding the eruption.

Finally, a striking feature of the rhyolites is their high silica content, with $\mathrm{SiO}_{2}$ whole-rock contents ranging from $76.61 \%$ to $77.14 \%$ (average $76.93 \%$ ) and glass contents just over $78 \%$ (Table 1 ). A scrutiny of published analyses (e.g. Walker, 1966; Sigmarsson and others, 1991) suggests that Prestahnúkur contains the highest silica rhyolites in Iceland. Such high-silica rhyolites should have higher viscosities than lower-silica rhyolites (e.g. Shaw, 1972). 


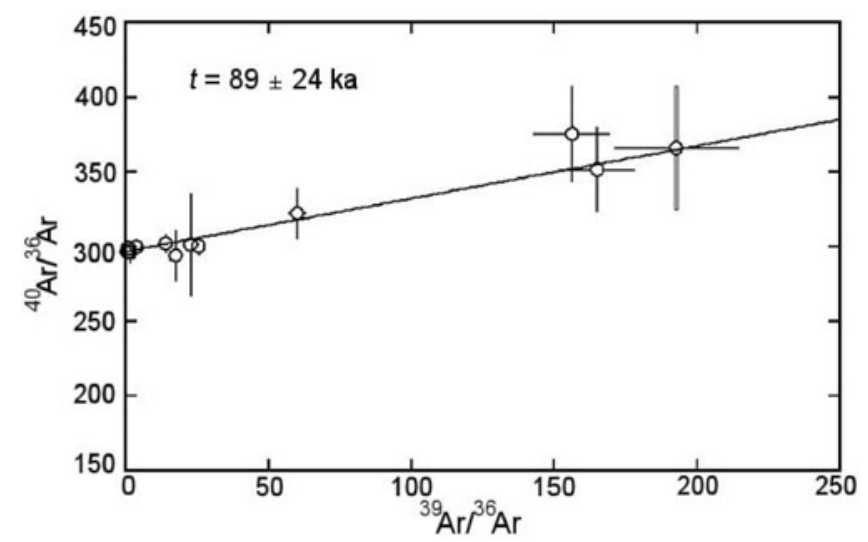

Fig. 11. ${ }^{40} \mathrm{Ar} /{ }^{36} \mathrm{Ar}-{ }^{39} \mathrm{Ar} /{ }^{36} \mathrm{Ar}$ correlation diagram for Prestahnúkur rhyolite. The regression line indicates mixing between a trapped Ar component of air ${ }^{40} \mathrm{Ar} /{ }^{36} \mathrm{Ar}=X \pm Y$ and a radiogenic component with ${ }^{40} \mathrm{Ar} /{ }^{39} \mathrm{Ar}$ given by the slope of the regression line of $89 \pm 24$ ka.

\section{WATER CONTENTS}

The dissolved water content in two obsidian samples was measured using a Thermo Nicolet Fourier transform infrared spectrometer (FTIR) at The Open University, UK. The FTIR used a liquid $\mathrm{N}_{2}$-cooled MCT-A detector, $\mathrm{KBr}$ beamsplitter, a spot size of $50 \mu \mathrm{m}$ and the sample chamber was purged with dried air. Five hundred scans were taken between 4000 and $600 \mathrm{~cm}^{-1}$. The thickness of double-polished sample wafers $(\sim 100 \mu \mathrm{m})$ was measured with a Mitutoyo digital displacement gauge. The height of the total water absorbance peak at $\sim 3550 \mathrm{~cm}^{-1}$ was used to calculate water contents using the Beer-Lambert law, a linear baseline correction and an absorption coefficient for rhyolitic glass of $78 \pm 4 \mathrm{~L} \mathrm{~mol}^{-1} \mathrm{~cm}^{-1}$ (Ihinger and others, 1994). There is insufficient total water in the samples for a significant quantity of molecular water to be present and no $\mathrm{CO}_{2}$ peak was detectable. The total water contents of samples PK1 (lower tier lava flow) and PK7 (summit lava) were found to be $0.10 \pm 0.01 \mathrm{wt} \%$ and $0.14 \pm 0.01 \mathrm{wt} \%$, respectively. (The accumulated errors from uncertainties in measurements and the absorption coefficient are about $10 \%$.)

\section{Ar-Ar DATING}

Three samples of rhyolite from two eruptive units (PK1 and PK7) were selected for Ar-Ar dating. Sub-millimetre fragments of glass matrix were hand picked under a binocular microscope to avoid phenocrysts that may have experienced a different magmatic history. Each sample was ultrasonically cleaned in methanol and de-ionised water before being irradiated. Samples and the Alder Creek age standard $(t=1.193 \pm 0.0001 \mathrm{Ma}$; Nomade and others, 2005) were irradiated for $0.5 \mathrm{hr}$ in the CLICIT (Cadmium-Lined In-Core Irradiation Tube) facility of the TRIGA reactor at Oregon State University. The J-value was determined from four aliquots of Alder Creek and interspersed among the rhyolite samples to give a weighted mean value of $0.000139 \pm 0.000004$. Neutron interference corrections were determined from $\mathrm{CaF}_{2}$ and $\mathrm{K}_{2} \mathrm{SO}_{4}$ included in the irradiation and lie within the errors of values previously determined by the OSU reactor (Nomade and others, 2005). Ar was extracted from rhyolite samples using 30 minute temperature steps at 500,
Table 1. XRF major and trace element data for six Prestahnúkur rhyolites. See Stevenson and others (2006) for details of analytical methods, equipment and uncertainties. Glass major element data represent an average of 37 microprobe analyses of PK4 (note that LOI is not determined during probe analysis)

\begin{tabular}{|c|c|c|c|c|c|c|c|}
\hline & PK1 & PK2 & PK3 & PK4 & PK6 & PK7 & Glass \\
\hline $\mathrm{SiO}_{2}$ & 77.14 & 76.80 & 77.12 & 77.04 & 76.85 & 76.61 & 78.23 \\
\hline $\mathrm{TiO}_{2}$ & 0.12 & 0.12 & 0.12 & 0.12 & 0.13 & 0.12 & 0.10 \\
\hline $\mathrm{Al}_{2} \mathrm{O}_{3}$ & 12.05 & 12.17 & 12.19 & 12.19 & 12.16 & 12.11 & 12.25 \\
\hline $\mathrm{Fe}_{2} \mathrm{O}_{3}$ & 1.59 & 1.74 & 1.74 & 1.73 & 1.75 & 1.73 & $1.33^{*}$ \\
\hline $\mathrm{MnO}$ & 0.04 & 0.05 & 0.05 & 0.05 & 0.05 & 0.05 & 0.04 \\
\hline $\mathrm{MgO}$ & 0.03 & 0.03 & 0.01 & 0.02 & 0.02 & 0.02 & 0.00 \\
\hline $\mathrm{CaO}$ & 0.96 & 1.05 & 1.04 & 1.04 & 1.05 & 1.04 & 0.93 \\
\hline $\mathrm{Na}_{2} \mathrm{O}$ & 4.29 & 4.39 & 4.37 & 4.41 & 4.42 & 4.40 & 1.19 \\
\hline $\mathrm{K}_{2} \mathrm{O}$ & 3.41 & 3.29 & 3.33 & 3.28 & 3.28 & 3.30 & 3.31 \\
\hline $\mathrm{P}_{2} \mathrm{O}_{5}$ & 0.01 & 0.01 & 0.01 & 0.01 & 0.01 & 0.01 & 0.01 \\
\hline LOI & 0.37 & 0.32 & 0.33 & 0.24 & 0.36 & 0.36 & - \\
\hline Total & 100.00 & 99.97 & 100.31 & 100.12 & 100.08 & 99.76 & 97.39 \\
\hline $\mathrm{Rb}$ & 82 & 79 & 79 & 79 & 80 & 79 & \\
\hline $\mathrm{Sr}$ & 68 & 78 & 76 & 76 & 78 & 77 & \\
\hline $\mathrm{Y}$ & 98 & 110 & 110 & 109 & 110 & 110 & \\
\hline $\mathrm{Zr}$ & 201 & 259 & 248 & 249 & 256 & 254 & \\
\hline $\mathrm{Nb}$ & 59 & 68 & 66 & 65 & 66 & 66 & \\
\hline $\mathrm{Ba}$ & 623 & 619 & 629 & 620 & 627 & 628 & \\
\hline $\mathrm{Pb}$ & 8 & 8 & 9 & 6 & 8 & 6 & \\
\hline Th & 12 & 12 & 13 & 14 & 14 & 13 & \\
\hline U & 2 & 3 & 4 & 4 & 4 & 4 & \\
\hline Sc & 2 & 2 & 3 & 1 & 1 & 1 & \\
\hline V & 3 & 5 & 3 & 4 & 0 & 4 & \\
\hline $\mathrm{Cr}$ & 4 & 4 & 4 & 4 & 4 & 3 & \\
\hline $\mathrm{Co}$ & 2 & 2 & 2 & 3 & 2 & 2 & \\
\hline $\mathrm{Ni}$ & 2 & 3 & 2 & 3 & 3 & 3 & \\
\hline $\mathrm{Cu}$ & 8 & 7 & 9 & 11 & 9 & 8 & \\
\hline $\mathrm{Zn}$ & 97 & 117 & 115 & 116 & 119 & 116 & \\
\hline $\mathrm{Ga}$ & 21 & 21 & 23 & 21 & 22 & 22 & \\
\hline Mo & 3 & 4 & 4 & 3 & 3 & 3 & \\
\hline As & 2 & 5 & 1 & 3 & 2 & 0 & \\
\hline$S$ & 24 & 24 & 23 & 21 & 21 & 20 & \\
\hline
\end{tabular}

*Data represent $\mathrm{Fe}$ as $\mathrm{FeO}_{\text {total }}$.

1100,1300 and $1500^{\circ} \mathrm{C}$ in a resistance furnace, with $>70 \%$ of the ${ }^{39} \mathrm{Ar}$ released in the $1100^{\circ} \mathrm{C}$ step. Raw data were corrected for discrimination, radioactive decay and neutron interference. Data from all samples show a good correlation on a ${ }^{40} \mathrm{Ar} /{ }^{36} \mathrm{~A}-{ }^{39} \mathrm{Ar} /{ }^{36} \mathrm{Ar}$ isotope correlation diagram (Fig. 11). The regression line was determined using the method of Williamson (1968) leading to an Ar-Ar age of $84 \pm 24 \mathrm{ka}$ ( $1 \sigma$ error). The mean squared weighted deviation (MSWD) value of $0.49(n=12)$ indicates an acceptable statistical correlation with $p=0.90$. However, the low MSDW suggests the analytical errors may be overestimated. Based upon the Y-intercept value of $296.6 \pm 1.4$ in Figure 11, the trapped component is most likely to be atmospheric argon. Radiogenic ${ }^{40} \mathrm{Ar}$ only accounts for between $8-21 \%$ of the total ${ }^{40} \mathrm{Ar}$ released at $1100^{\circ} \mathrm{C}$.

\section{DISCUSSION}

A model for the formation of Prestahnúkur is proposed and ice-volcano interactions and climatic implications are discussed. 
Table 2. Compilation of data on the interglacial-glacial transition between the Eemian and Weichselian (Lowe and Walker, 1997)

\begin{tabular}{|c|c|c|c|c|c|c|}
\hline Ol stage/substage & $5 e$ & $5 d$ & $5 c$ & $5 b$ & $5 a$ & 4 \\
\hline Terminology & Eemian interglacial & \multicolumn{4}{|c|}{ Lower Weichselian } & Middle Weichselian \\
\hline Conditions & Warm & Cold & Warm & Cold & Warm & Cold \\
\hline Midpoints $5 \mathrm{~d}$ to $5 \mathrm{a}$ & (ended $115 \mathrm{ka}$ ) & $110 \mathrm{ka}$ & $100 \mathrm{ka}$ & $91 \mathrm{ka}$ & $75 \mathrm{ka}$ & (began $70 \mathrm{ka}$ ) \\
\hline Air T $\left({ }^{\circ} \mathrm{C}\right.$ lower $)$ & & $8-10$ & $6-7$ & $5-7$ & $2-3$ & \\
\hline Sea level drop & & $60 \mathrm{~m}$ & $20-25 \mathrm{~m}$ & $50 \mathrm{~m}$ & $20-25 \mathrm{~m}$ & \\
\hline
\end{tabular}

\section{Model for the formation of Prestahnúkur}

A 3-stage preliminary model is proposed. Stage 1 involved effusion at the ice-bedrock interface. Extensive interactions with meltwater caused quenching and fragmentation of the margins of the magma leading to the formation of lobebearing hyaloclastite. Significant volumes of hyaloclastite have not been reported from subglacial eruptions of evolved magmas elsewhere, such as the Garibaldi Volcanic Field or The Table (Kelman and others, 2002). In these locations, eruptions took place on steep topography, which would have promoted drainage of meltwater. However, the preeruption topography at Prestahnúkur was almost flat. Although theoretical calculations suggest that meltwater generation from eruptions of evolved magmas is insufficiently rapid to generate water-filled cavities (Höskuldsson and Sparks, 1997), the lobe-bearing hyaloclastite can be produced provided that meltwater escape is inefficient and the breccia pile has been left soggy. Magmaticallyfragmented tephras, which are ubiquitous in basal pedestal deposits at Torfajökull and Kerlingarfjöll rhyolite tuyas (Tuffen and others, 2002; Stevenson, 2005) are scarce at Prestahnúkur. This may reflect one or more of lower initial volatile contents, high confining pressure (which implies thick ice), high magma viscosity or extensive degassing prior to eruption.

Stage 2 involved the formation of the lower tier via sill intrusion at the ice-edifice interface. Contact with wet substrate generated peperite-like sheet bases, while hyaloclastite carapaces indicate flow top wetting (via melting of overlying ice).

Stage 3 involved the formation of the upper and southern tiers, with the production of single, stacked and slopedraping sheets. Peperite-like bases and hyaloclastite carapaces were generated by flow along the edifice-ice boundary. On the upper tier at $\sim 1100 \mathrm{~m}$ altitude, sheets on the north and northwest ended at ice walls developing steeply-ramped termini. Explosions and collapses of lava bodies generated clasts which were deposited, along with reworked carapace material, in localized water bodies. These polymictic breccias demonstrate that meltwater was important throughout the eruption.

The original volatile content of the Prestahnúkur magma is not known. FTIR measurements on obsidians show low water contents of only $0.10-0.14 \mathrm{wt} \%$. However, some volatile loss (degassing) is required to generate the thick pumiceous carapaces on the lava tiers and the vesicular clasts in the lobe-hyaloclastite complexes, and so the original volatile content will have been greater than 0.10 $0.14 w t \%$. Evidence for volatile-driven fragmentation at Prestahnúkur is however rare, whereas it is abundant at the rhyolite tuyas of Torfajökull and Kerlingarfjöll (Tuffen and others, 2002; Stevenson, 2005), where higher volatile contents (determined by FTIR) of up to $0.61 \mathrm{wt} \%$ have been reported (Tuffen, 2001) on edifices of similar vertical extent as Prestahnúkur. Consequently, we suggest that the original volatile content of the Prestahnúkur rhyolite was probably $0.2-0.5 \mathrm{wt} \%$, which would imply that the magma originally had a lower volatile content than that of other Icelandic rhyolite tuyas (Tuffen and others, 2002; Stevenson, 2005).

Estimating eruption durations depends on the mass discharge rate selected (e.g. Fink and Griffiths, 1998). Low discharge rates have been proposed: $0.5-1.6 \mathrm{~m}^{3} \mathrm{~s}^{-1}$ at an active dacite lava flow $\left(62.5 \% \mathrm{SiO}_{2}\right)$ by Harris and others (2004); $0.1 \mathrm{~m}^{3} \mathrm{~s}^{-1}$ for a submarine-emergent silicic lava dome eruption $\left(68-72 \% \mathrm{SiO}_{2}\right.$ ) in $1934-35$ by Maeno and Taniguchi (2006); and $0.1-10 \mathrm{~m}^{3} \mathrm{~s}^{-1}$ for the effusive eruption of the Bláhnúkur subglacial rhyolite by Tuffen and others (2001). In contrast, higher discharge rates of 100$1000 \mathrm{~m}^{3} \mathrm{~s}^{-1}$ were proposed by Höskuldsson and Sparks (1997) for small-volume fissure-fed rhyolitic eruptions, while Tuffen and others (2002) argued that rates of 10$100 \mathrm{~m}^{3} \mathrm{~s}^{-1}$ were appropriate for rhyolite tuyas. Using rates of 1,10 and $100 \mathrm{~m}^{3} \mathrm{~s}^{-1}$ and Prestahnúkur's DRE volume of $0.6 \mathrm{~km}^{3}$ gives eruption durations of 19 years, 2 years and 69 days, respectively. We consider an average rate between 1 and $10 \mathrm{~m}^{3} \mathrm{~s}^{-1}$ to be reasonable given that Pyle (2000) has argued that magma discharge rates are roughly proportional to erupted volume, and given the paucity of volatile-driven fragmentation at Prestahnúkur. This duration (2-19 years) is broadly consistent with the 3.5-4 year duration of the subaqueous-to-emergent rhyolite eruption of Tuluman (Reynolds and others, 1980), and could have allowed substantial replenishment of melted ice (given rates of inward ice flow of $10^{-5}$ to $10^{-6} \mathrm{~m} \mathrm{~s}^{-1}$, Aðalgeirsdóttir and others, 2000).

\section{Ice-volcano interactions}

Ice-contact features in upper tier sheets at $\sim 1100 \mathrm{~m}$ altitude (just $\sim 120 \mathrm{~m}$ below the present summit) suggest that ice may have covered the edifice throughout its construction. This would explain the evidence for meltwater interaction at all stratigraphic levels. As no significant emergent phase has been found, Prestahnúkur could be the product of an entirely subglacial eruption. If this is correct, then as ice cauldron depths of up to $150 \mathrm{~m}$ have been observed in ice-sheet surfaces above heat sources that are melting basal ice (Guðmundsson and others, 2004), and assuming that a similarly-sized cauldron formed in the ice above Prestahnúkur, this would imply that the ice was at least 700 m thick during the eruption. This is likely to be a minimum thickness, as larger cauldrons may form above larger edifices.

Finally, while more sophisticated models could be constructed that incorporate ice roof collapse, ice wall melt-back and encroachment, heavy snowfall and so on, we 


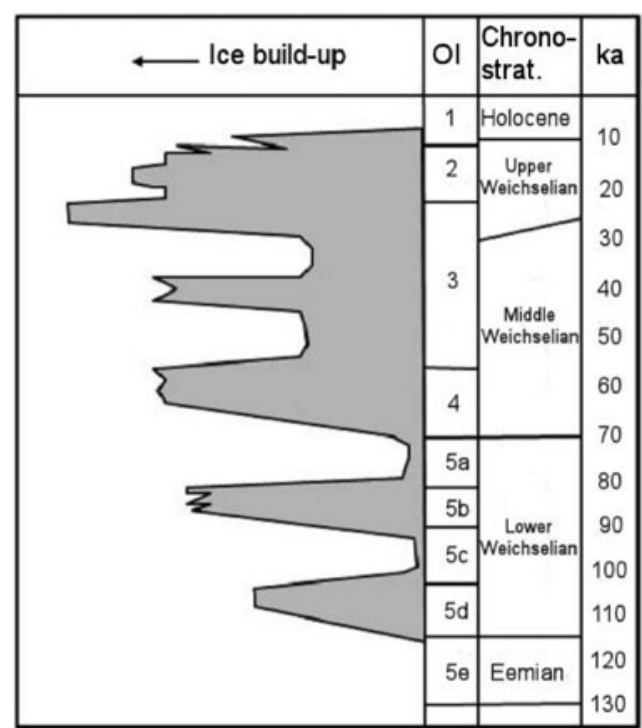

Fig. 12. Schematic glaciation curve for the last interglacial-glacial cycle in Scandinavia. The curve indicates periods of ice accumulation (to the left) and ice recession (to the right). Ol = oxygen isotope. After Mangerud (1991).

believe that the present entirely subglacial model provides a sufficient and simple explanation for the volcanological features we have observed.

\section{Climatic implications}

Table 2 summarises conditions during the Lower Weichselian transition between the Eemian interglacial (Oxygen Isoptope (OI) substage 5e) and full glacial conditions of OI stage 4, while Figure 12 shows relative temperature fluctuations from the Eemian to the Holocene. The span of the $\pm 24 \mathrm{ka}(1 \sigma)$ error on Prestahnúkur's $89 \mathrm{ka}$ Ar-Ar age implies eruption from $113 \mathrm{ka}$ (substage $5 \mathrm{~d}$ ) to $65 \mathrm{ka}$ in early Ol stage 4. However, as noted earlier, the low MSWD suggests that analytical errors may be overestimated, so we consider it reasonable to assume that eruption occurred during the actual interglacial-glacial transition (i.e. OI substages $5 \mathrm{~d}$ to $5 \mathrm{a}$ ).

In Figure 12, the rapid switching between cold and warm (interstadial) conditions over $10^{3}-10^{4}$ years from $5 \mathrm{e}$ to $5 \mathrm{a}$ is apparent. Evidence from ice-rafted debris suggests that during cold periods ( $5 \mathrm{~d}$ and $5 \mathrm{~b}$ ) the rapid build-up of land ice (McManus and others, 1994) reached $\sim 50 \%$ of that at the last glacial maximum (18-22 ka), while evidence from interstadial sediments (Lundqvist, 1986) indicates nearcomplete deglaciation during warm periods (5c and $5 a$ ). Note that ambient air temperatures (even during the $5 \mathrm{c}$ and $5 \mathrm{a}$ interstadials) were consistently lower than during interglacial conditions (Table 2).

If we assume that Prestahnúkur was entirely ice-covered during its construction and that it erupted when ice was at a maximum thickness, then this implies eruption when (at a conservative estimate) there was $>700 \mathrm{~m}$ of ice in this area at the time. Given this ice thickness, eruption is more likely during a cold substage than during a warm substage, but the error on the Ar-Ar age does not allow us to say whether this was during either cold substage $5 \mathrm{~d}$ (mid-point $110 \mathrm{ka}$ ) or $5 \mathrm{~b}$ (mid-point $91 \mathrm{ka}$ ). Nevertheless, the eruption of Prestahnúkur during this interglacial-glacial transition (when there were rapid fluctuations in temperature) supports models arguing for very rapid accumulation of land-based ice in response to global cooling (e.g. Raymo and others, 1998), as it can be seen from Figure 12 that the timescales involved are $\sim 10^{3}$ years. In conclusion, this is the first time that icevolcano interactions in combination with Ar-Ar dating has provided a reasonable estimate for ice thicknesses during an interglacial-glacial transition at an Icelandic locality.

\section{CONCLUSIONS}

Prestahnúkur is a glaciovolcanic edifice constructed during the eruption of a single batch of high-silica rhyolite. The eruption was effusive, and initially produced lobehyaloclastite breccias followed by a complex sequence of lava sheets, interpreted as sills that intruded the edifice-ice interface.

Exposures reveal no evidence for a substantial early phase of magmatic (i.e. volatile-driven) fragmentation. It is therefore suggested that the erupting magma had a relatively low volatile content $(0.2-0.5 \mathrm{wt} \%)$, and had an eruption rate of between 1 and $10 \mathrm{~m}^{3} \mathrm{~s}^{-1}$, generating an eruption duration of 2-19 years. Steep ramping of lava flow termini suggests contact with ice barriers, implying ice thicknesses of at least $450 \mathrm{~m}$. The edifice may have been ice-covered throughout its construction, implying a minimum ice thickness of $700 \mathrm{~m}$. The age of $89 \pm 24 \mathrm{ka}$ suggests eruption during OI stage 5 (possibly one of the cold spikes indicated by substages $5 d$ or $5 b)$.

This supports models that argue for the very rapid accumulation of land-based ice even during short-lived cold periods, as both these substages reached their maxima in under $\sim 9$ ka.

\section{ACKNOWLEDGEMENTS}

We thank J. Watson for assistance with XRF, K. Sharma for assistance with FTIR and J. McGarvie for fieldwork support. Special thanks go to G. Ívarsson and M.T. Guðmundsson for transportation in Iceland. D.McG. was supported by The Open University Staff Tutor Research Fund. Finally, we would like to express our sincere thanks to D. Crown and S. Anderson for supportive and helpful reviews.

\section{REFERENCES}

Aðalgeirsdóttir, G., G.H. Guðmundsson and H. Björnsson. 2000. The response of a glacier to a surface disturbance: a case study on Vatnajökull ice cap, Iceland. Ann. Glaciol., 31, 104-110.

Anderson, S.W., E.R. Stofan, J.J. Plaut and D.A. Crown. 1998. Block size distributions on silicic lava flow surfaces: implications for emplacement conditions. GSA Bulletin, 110(10), 1258-1267.

Baker, B.H. and L.F. Henage. 1977. Compositional changes during crystallization of some peralkaline silicic lavas of the Kenya rift valley. J. Volcan. Geotherm. Res., 2(1), 17-28.

Cas, R.A.F, R.L. Allen, S.W. Bull, B.A. Clifford and J.V. Wright. 1990. Subaqueous, rhyolitic dome-top tuff cones: a model based on the Devonian Bunga Beds, southeastern Australia and a modern analogue. Bull. Volcanol., 52(3), 159-174.

DeRita, D., G. Giordano and A. Cecili. 2001. A model for submarine rhyolite dome growth: Ponza Island (central Italy). J. Volcan. Geotherm. Res., 107(4), 221-239.

Fink, J.H. and R.W. Griffiths. 1998. Morphology, eruption rates, and rheology of lava domes: Insights from laboratory models. J. Geophys. Res., 103(B1), 527-546. 
Fink, J.H. and S.W. Anderson. 2000. Lava domes and coulees. In Sigurdsson, H., B. Houghton, H. Rymer, J. Stix and S. McNutt, eds. Encyclopedia of Volcanoes. London, Academic Press, 403-418.

Fink, J.H., S. Anderson and C.R. Manley. 1992. Textural constraints on effusive silicic volcanism - beyond the permeable foam model. J. Geophys. Res. - Solid Earth, 97(B6), 9073-9083.

Follieri, M., D. Magri and L. Sadori. 1989. Pollen stratigraphical synthesis from Valle di Castiglione (Roma). Quat. Int., 3/4, $81-84$.

Goto, Y. and N. Tsuchiya. 2004. Morphology and growth style of a Miocene submarine dacite lava dome at Atsumi, northeast Japan. J. Volcan. Geotherm. Res., 134(4), 255-275.

Guðmundsson, M.T., F. Sigmundsson, H. Björnsson and p. Högnadóttir. 2004. The 1996 eruption at Gjálp, Vatnajökull ice cap, Iceland: efficiency of heat transfer, ice deformation and subglacial water pressure. Bull. Volcanol., 66(1), 46-65.

Guiot, J. 1990. Methodology of the last climatic cycle reconstruction in France from pollen data. Palaeogeogr., Palaeoclimatol., Palaeoecol., 80(1), 49-69.

Harris, A.J.L., L.P. Flynn, O. Matias, W.I. Rose and J. Cornejo. 2004. The evolution of an active silicic lava flow field: an ETM+ perspective. J. Volcan. Geotherm. Res., 135(1-2), 147-168.

Höskuldsson, A. and R.S.J. Sparks. 1997. Thermodynamics and fluid dynamics of effusive subglacial eruptions. Bull. Volcanol., 59(3), 219-230.

Hunns, S.R. and J. McPhie. 1999. Pumiceous peperite in a submarine volcanic succession at Mount Chalmers, Queensland, Australia. J. Volcan. Geotherm. Res., 88(4), 239-254.

Ihinger, P.D., R.L. Hervig and P.F. McMillan. 1994. Analytical methods for volatiles in glasses. Reviews in Mineralology and Geochemistry, 30(1), 67-121.

Imbrie, J., A. Mclntyre and A. Mix. 1989. Oceanic response to orbital forcing in the late Quaternary: observational and experimental strategies. In Berger, A., S. Schneider and J.C. Duplessy, eds. Climate and Geo-sciences. Boston, Kluwer, 121-165.

Kelman, M.C., J.K. Russel and C.J. Hickson. 2002. Effusive intermediate glaciovolcanism in the Garibaldi Volcanic Belt, southwestern British Columbia, Canada. In Smellie, J.L. and M.G. Chapman, eds. Volcano-Ice Interaction on Earth and Mars (Geological Society Special Publication, No. 202). London, Geological Society of London, 195-211.

Lescinsky, D.T. and J.H. Fink. 2000. Lava and ice interaction at stratovolcanoes: use of characteristic features to determine past glacial extents and future volcanic hazards. J. Geophys. Res., 105(B10), 23,711-23,726.

Lowe, J.J. and M.J.C. Walker. 1997. Reconstructing Quaternary Environments. Essex, Pearson Education.

Lunqvist, J. 1986. Stratigraphy of the central area of the Scandinavian glaciation. Quat. Sci. Rev., 5, 251-268.

MacDonald, R., D.W. McGarvie, H. Pinkerton, R.L. Smith and A. Palacz. 1990. Petrogenetic evolution of the Torfajökull Volcanic Complex, Iceland I. Relationship between the magma types. J. Petrol., 31(2), 429-459.

McGarvie, D.W. 1985. Volcanology and petrology of mixed magmas and rhyolites from the Torfajökull volcanic complex. (PhD Thesis, University of Lancaster.)

McGarvie, D.W., R. MacDonald, H. Pinkerton and R.L. Smith. 1990. Petrogenetic evolution of the Torfajökull Volcanic Complex, Iceland II. The role of magma mixing. J. Petrol., 31(2), 461-481.

McManus, J.F., G.C. Bond, W.S. Broecker, S. Johnsen, L. Labeyrie and S. Higgins. 1994. High-resolution climate records from the North Atlantic during the last interglacial. Nature, 371(6495), 326-329.

Maeno, F. and H. Taniguchi. 2006. Silicic lava dome growth in the 1934-1935 Showa Iwo-jima eruption, Kikai caldera, south of Kyushu, Japan. Bull. Volcanol., 68(7/8), 673-688.

Mangerud, J. 1991. The last interglacial/glacial cycle in Northern Europe. In Shane, L.C.K. and E. Cushing, eds. Quaternary Landscapes. Minneapolis, University of Minnesota Press, 38-75.
Nomade, S. and 7 others. 2005. Alder Creek sanidine (ACs-2): A Quaternary ${ }^{40} \mathrm{Ar} /{ }^{39} \mathrm{Ar}$ dating standard tied to the Cobb Mountain geomagnetic event. Chemical Geol., 218(3-4), 315-338.

Orth, K. and J. McPhie. 2003. Textures formed during emplacement and cooling of a Palaeoproterozoic, small-volume rhyolitic sill. J. Volcan. Geotherm. Res., 128(4), 341-362.

Piper, J.D.A. 1973. Volcanic history and tectonics of the North Langjökull region, Central Iceland. Can. J. Earth Sci., 10, 164-179.

Pyle, D.M. 2000. Sizes of volcanic eruptions. In Sigurdsson, H., B. Houghton, H. Rymer, J. Stix and S. McNutt, eds. Encyclopedia of Volcanoes. London, Academic Press, 263-269.

Raymo, M.E., K. Ganley, S. Carter, D.W. Oppo and J. McManus. 1998. Millennial-scale climate instability during the early Pleistocene epoch. Nature, 392, 699-702.

Reynolds, M.A, J.G. Best and R.W. Johnson. 1980. Eruption of Tuluman Volcano: rhyolitic volcanic activity in the northern Bismarck Sea. Geological Survey of Papua New Guinea Memoir, 7.

Saemundsson, K. 1992. Geology of the Thingvallavatn area. Oikos, 64, 40-68.

Shaw, H.R. 1972. Viscosities of magmatic silicate liquids; an empirical method of prediction. Am. J. Sci., 272, 870-893.

Sigmarsson, O., C. Hemond, M. Condomines, S. Fourcade and N. Oskarsson. 1991. Origin of silicic magma in Iceland revealed by Th isotopes. Geology, 19(6), 621-624.

Smellie, J.L. 2000. Subglacial eruptions. In Sigurdsson, H., B. Houghton, H. Rymer, J. Stix and S. McNutt, eds. Encyclopedia of Volcanoes. London, Academic Press, 269-285.

Stevenson, J.A. 2005. Volcano-ice interaction at Öræfajökull and Kerlingarfjöll, Iceland. (PhD Thesis, The Open University.)

Stevenson, J.A., D.W. McGarvie, J.L. Smellie and J.S. Gilbert. 2006. Subglacial and ice-contact volcanism at the Öræajökull stratovolcano, Iceland. Bull. Volcanol., 68(7/8), 737-752.

Stevenson, R.J., R.M. Briggs and A.P.W. Hodder. 1994. Physical volcanology and emplacement history of the Ben Lomond rhyolite lava flow, Taupo Volcanic Centre, New Zealand. NZ J. Geol. Geophys., 37(3), 345-358.

Stewart, A.L. and J. McPhie. 2006. Facies architecture and Late Pliocene - Pleistocene evolution of a felsic volcanic island, Milos, Greece. Bull. Volcanol., 68(7/8), 703-726.

Tuffen, H. 2001. Subglacial rhyolite volcanism at Torfajökull, Iceland. (PhD Thesis, The Open University.)

Tuffen, H., J. Gilbert and D. McGarvie. 2001. Products of an effusive subglacial rhyolite eruption: Bláhnúkur, Torfajökull, Iceland. Bull. Volcanol., 63(2-3), 179-190.

Tuffen, H., D.W. McGarvie, J.S. Gilbert and H. Pinkerton. 2002. Physical volcanology of a subglacial-to-emergent rhyolitic tuya at Rauðufossafjöll, Torfajökull, Iceland. In Smellie, J.L. and M.G. Chapman, eds. Volcano-Ice Interaction on Earth and Mars (Geological Society Special Publication, No. 202). London, Geological Society of London, 213-236.

Walker, G.P.L. 1966. Acid volcanic rocks in Iceland. Bull. Volcanol., 29, 375-402.

Werner, R., H.-U. Schmincke and G.E. Sigvaldason. 1996. A new model for the evolution of table mountains: volcanological and petrological evidence from Herðubreið and Herðubreiðartögl volcanoes (Iceland). Geol. Rundsch., 85(2), 390-397.

White, J.D.L., J. McPhie and I. Skilling. 2000. Peperite: a useful genetic term. Bull. Volcanol., 62(1), 65-66.

Williamson, J.H. 1968. Least-squares fitting of a straight line. Can. J. Phys., 46, 1845-1847.

Wilson, L. and I.J.W. Head. 2002. Heat transfer and melting in subglacial basaltic volcanic eruptions: implications for volcanic deposit morphology and meltwater volumes. In Smellie, J.L. and M.G. Chapman, eds. Volcano-ice interaction on Earth and Mars. London, Geological Society, 5-26. (Special publication 202.)

Yamagishi, H. and E. Dimroth. 1987. Studies on the Neogene subaqueous lavas and hyaloclastites in southwest Hokkaido. Geological Survey of Hokkaido, 59. 55-117. 